\title{
Peritoneal Disease Severity Score Predicts the Prognosis of Peritoneal Metastasis of Colorectal Origin: A 10-year Longitudinal Analysis of a Single-center Experience
}

\author{
Peritoneal Yüzey Hastalığı Şiddet Skorunun Kolorektal Kansere Sekonder \\ Peritoneal Metastazlı Hastalarda Prognozu Öngörme Gücü: Tek Merkezin \\ 10 Yıllık Deneyimi
}

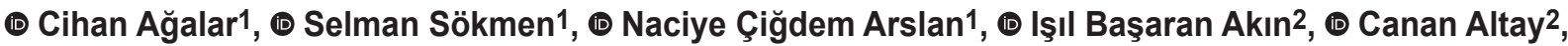 \\ (1) Aras Emre Canda1, (1) Funda Obuz², (1) Sülen Sarıoğlu³ \\ 1Dokuz Eylül University Faculty of Medicine, Department of General Surgery, İzmir, Turkey \\ 2Dokuz Eylül University Faculty of Medicine, Department of Radiology, İzmir, Turkey \\ 3Dokuz Eylül University Faculty of Medicine, Department of Pathology, İzmir, Turkey
}

\section{IIIIIIII ABSTRACT}

\begin{abstract}
Aim: Peritoneal Surface Disease Severity score (PSDSS) has been used in the evaluation of patients who are scheduled for cytoreductive surgery (CRS) and hyperthermic intraperitoneal chemotherapy (HIPEC) for peritoneal metastasis of colorectal origin (PMCO). The aim of this study was to evaluate the validity of PSDSS in predicting prognosis in patients who underwent CRS + HIPEC for PMCO at our center.

Method: Demographic data, operation data, histopathological features, perioperative morbidity and mortality, and oncologic follow-up data were obtained retrospectively from the database and analyzed. Peritoneal carcinomatosis index (PCI) values were calculated from preoperative computed tomographies. PSDSS was calculated by evaluating clinical symptoms, PCI and histology of primary tumor. Two PSDSS groups were formed: PSDSS 1 and 2 groups as low PSDSS group, and PSDSS 3 and 4 groups as high PSDSS group.

Results: Sixty-one patients, including 36 females (59\%) and 25 males (41\%), with PMCO who underwent CRS and HIPEC were included in the study. Forty-four patients were enrolled to the low PSDSS group and 17 patients were enrolled to the high PSDSS group. Three patients (3.2\%) died during the perioperative period. Twenty-one patients (34.4\%) had perioperative complications. The mean follow-up was $35.0 \pm 23.2$ months. During the follow-up period, 36 patients (59\%) had recurrence and 44 patients (72.1\%) died. The mean survival was $46.5 \pm 5.5$ months, and $1-, 3$ - and 5 -year survival rates were $85 \%, 47 \%$ and $21 \%$, respectively. There was no correlation between low and high PSDSS groups in terms of morbidity and recurrence ( $\mathrm{p}=0.486$ and $\mathrm{p}=0.385$, respectively). Mortality was more frequent in high PSDSS group (94\% vs $63 \%$; $\mathrm{p}=0.024$ ). The mean survival of patients in the low PSDSS group was significantly longer than in the high PSDSS group (57.2 \pm 6.7 months vs $16.5 \pm 2.6$ months; $\mathrm{p}=0.001)$.

Conclusion: The findings of this study demonstrated the validity of PSDSS in predicting prognosis in patients with PMCO who were scheduled for CRS and HIPEC.
\end{abstract}

Keywords: Colorectal cancer, peritoneal metastasis, peritoneal carcinomatosis, Peritoneal Surface Disease Severity score, hyperthermic intraperitoneal chemotherapy

\section{|IIIIIIII| ÖZ}

\begin{abstract}
Amaç: Kolorektal kansere ikincil peritoneal metastaz (KRKPM) nedeniyle sitoredüktif cerrahi (SRC) ve hipertermik karın içi kemoterapi (HIPEK) uygulanacak hastaların değerlendirilmesinde, Peritoneal Yüzey Hastalığı Şiddet skoru (PYHŞS) kullanılmaya başlanmıştır. Bu çalışmanın amacı merkezimizde KRKPM nedeniyle SRC + HIPEK uygulanan hastalarda PYHŞS’nin prognozu öngörmedeki geçerliliğini değerlendirmektir.

Yöntem: Hastaların demografik bilgileri, operatif veriler, histopatolojik özelllikler, perioperatif morbidite ve mortalite bilgileri, onkolojik izlem verileri prospektif olarak doldurulan veri tabanının retrospektif incelenmesi ile elde edildi. Hastaların preoperatif dönemdeki bilgisayarlı tomografilerinden peritoneal karsinomatozis indeks (PKİ) değerleri hesaplandı. PYHŞS klinik semptomlar, PKİ ve primer tümörün histolojisi değerlendirilerek
\end{abstract}

Address for Correspondence/Yazışma Adresi: Cihan Ağalar MD,

Dokuz Eylül University Faculty of Medicine, Department of General Surgery, İzmir, Turkey

Phone: +90 5062922575 E-mail: cihan.agalar@deu.edu.tr ORCID ID: orcid.org/0000-0002-9848-0326

口.1.t. Received/Geliş Tarihi: 24.03.2019 Accepted/Kabul Tarihi: 17.04.2019

${ }^{\oplus}$ Copyright 2019 by Turkish Society of Colon and Rectal Surgery

Turkish Journal of Colorectal Disease published by Galenos Publishing House. 
hesaplandı. Dört PYHŞS grubu oluşturuldu: PYHŞS 1 ve 2 grupları, düşük PYHŞS grubu; PYHŞS 3 ve 4 grupları ise yüksek PYHŞS grubu olarak katmanlandırıldı.

Bulgular: SRC ve HIPEK uygulanmış 61 KRKPM'li hasta [36 kadın (\%59), 25 erkek (\%41)] çalışmaya dahil edildi. Kırk dört hasta düşük PYHŞS grubuna, 17 hasta yüksek PYHŞS grubuna eklendi. Üç hasta $(\% 3,2)$ perioperatif dönemde eksitus oldu. Yirmi bir hastada $(\% 34,4)$ perioperatuvar

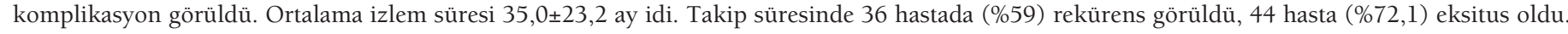
Ortalama sağkalım süresi 46,5 $\pm 5,5$ ay olup. Bir, üç ve 5 yıllık sağkalımlar sırasıyla \%85, \%47 ve \%21 olarak saptandı. Morbidite ve rekürens gelişimi ile düşük ve yüksek PYHŞS grupları arasında ilişki saptanmadı (sırasıyla p=0,486 ve p=0,385). Mortalite yüksek PYHŞS grubunda daha sık görüldü (\%94'e karşı \%63; p=0,024). Düşük PYHŞS grubundaki hastaların ortalama sağkalımı, yüksek PYHŞS grubundakilere göre anlamlı olarak daha uzun bulundu $(57,2 \pm 6,7$ aya karşı $16,5 \pm 2,6$ ay; $\mathrm{p}=0,001)$.

Sonuç: Bu çalışmadaki bulgular, KRKPM'li hastaların SRC ve HIPEK planlanan hasta grubunda PYHŞS'nin prognozu öngörmede geçerliliğini göstermiştir.

Anahtar Kelimeler: Kolorektal kanser, peritoneal metastaz, peritoneal karsinomatozis, Peritoneal Yüzey Hastalığı Şiddet skoru, hipertermik karın içi kemoterapi

\section{Introduction}

Approximately $10 \%$ of patients with colorectal carcinoma develop peritoneal metastasis (PM). ${ }^{1}$ While the mean survival of this patient group was 7 months by conventional treatments ${ }^{2}, 5$-year survival rate is increased to $20-45 \%$ with the addition of hyperthermic intraperitoneal chemotherapy (HIPEC) to the cytoreductive surgery (CRS) technique described by Sugarbaker. ${ }^{3,4}$ Peritoneal cancer index (PCI) is the most commonly used prognostic indicator in patients diagnosed with PM of colorectal origin (PMCO). ${ }^{5,6}$ The biggest accepted deficiency of the PCI is that it can only be calculated during surgical exploration. ${ }^{7}$ Complete CRS cannot be performed in $25 \%$ of patients who underwent surgery due to $\mathrm{PMCO} .{ }^{8}$ Patient selection is very important for achieving high survival with acceptable morbidity in patients with advanced stage cancer who will undergo both high-cost and high-risk surgical procedures such as CRS and HIPEC, so patients need to be graded according to the severity of the disease in the preoperative period. Pelz et al. ${ }^{9}$ defined a new staging system called Peritoneal Surface Disease Severity score (PSDSS), which is calculated by using the clinical symptoms of patients, the extent of carcinomatosis and primary histopathology. In single and multicenter studies, this staging system has been shown to be effective in predicting prognosis in patients with PMCO. ${ }^{6,9,10,11,12,13}$ The aim of this study was to evaluate the validity of PSDSS in prognosis in patients who underwent CRS and HIPEC for PMCO at our center.

\section{Materials and Methods}

Between 2005 and 2015, 291 patients underwent CRS and HIPEC at our clinic. The primary tumors of these patients were colorectal cancer in 93 patients (32\%), ovarian cancer in 73 patients (25\%), appendix cancer and pseudomyxoma peritonei in 33 patients (11\%), and primary cancers of the peritoneum and peritoneal malignant mesothelioma in 35 patients (12\%). Sixty-one patients with PMCO, including 36 women (59\%) and 25 men (41\%), were included in the study. Extra-abdominal metastasis, widespread small bowel involvement, extensive portal pedicle invasion, plaque-like small bowel mesentery involvement, extensive involvement in the pancreaticoduodenal region, bilateral ureter invasion, extensive and deep involvement of pelvic wall and major abdominal vessel invasion were accepted as contraindication for CRS and HIPEC. Patients without complete cytoreduction (CC) CC-2, CC-3, patients without preoperative computed tomography (CT) scans or CT scans with poor quality, and patients who died during the perioperative period (0-90 days or postoperative hospital stay) were not included in the study. According to these criteria, 32 patients (34.4\%) were excluded from the study. The reasons for exclusion from the study were CT-related problems in 21 patients (22.5\%), perioperative mortality in 3 patients (3.2\%), and incomplete cytoreduction in 8 patients $(8.7 \%)$. Complications were graded according to Clavien-Dindo (C-D) classification. Grade 1-2 complications were classified as minor and grade 3-4 complications were classified as major. ${ }^{14}$ Demographic data, operative data (operative time, cytoreduction status), histopathological features, and perioperative morbidity and mortality data were obtained by retrospectively examining the database. Oncologic follow-up data (intraabdominal recurrence and/or distant metastasis) and date of death of patients were obtained from hospital database and national population registration system. PCI scores obtained by evaluation of preoperative CT scans of the patients were calculated by three radiologists experienced in abdominal radiology who were unaware of the operative and followup data. Approval was obtained from the non-invasive local ethics committee for the study. PSDSS was calculated by evaluating the clinical symptoms, PCI score and histology of the primary tumor as defined in the study of Pelz et al. ${ }^{9}$ and four PSDSS groups were formed according to the scores of the patients. (Table 1). PSDSS 1 and 2 groups were 
evaluated as low PSDSS group, and PSDSS 3 and 4 groups as high PSDSS group.

\section{Statistical Analysis}

SPSS 22 (SPSS, Chicago, Ill) was used for all statistical analyzes. Chi-square test was used for comparison of categorical variables and Student-t test was used for comparison of numerical variables. The time from surgery to death was considered as mean survival. "Kaplan-Meier estimator (K-M)" was used to calculate overall survival rates, and "log-rank test" was used to compare the differences between survival curves. $\mathrm{P}<0.05$ was considered statistically significant.

\section{Results}

The mean age of the 61 patients included in the study was $53.3 \pm 14.1$ years $(53.5 \pm 14.6$ years for female patients and $53.1 \pm 13.6$ years for male patients). Twenty-seven patients (44\%) had synchronous and 34 (56\%) had metachronous PM. At the time of the surgery, none of the patients had distant metastases. When the patients were classified according to their symptoms, there were no symptoms in 8 patients (13.1\%), mild symptoms in 42 patients (68.8\%) and severe symptoms in 11 patients (18.1\%). PCI scores obtained by examining preoperative CT scans were $<10$ in 25 patients ( $41 \%$ ), between $10-20$ in 25 patients (41\%) and $>20$ in 11 patients (18\%). According to histopathological results, five patients (8.2\%) had well-differentiated carcinoma and node $(\mathrm{N})$ No lymph N involvement, 52 patients $(85.2 \%)$ had moderately differentiated carcinoma and N1-N2 lymph N involvement, and four patients (6.6\%) had poorly differentiated or signet ring cell carcinoma. The mean PSDSS was 7.9 \pm 4.07 (range, 2-17). According to these data, four patients $(6.6 \%)$ were included in the PSDSS 1 group, 40 patients (65.6\%) were included in the PSDSS 2 group, four patients (6.6\%) were included in the PSDSS 3 group, and 13 patients (21.3\%) were included in the PSDSS 4 group. The demographic and clinical data of the patients are summarized in Table 2. The mean operative time of the patients was $328.9 \pm 129.7$ (range, 125-720) minutes. Eleven patients (18\%) were followed up in the intensive care unit (ICU) postoperatively. The mean ICU stay was $1.4 \pm 0.6$ days, and the mean postoperative hospital stay was $15.1 \pm 10.3$ days. A total of 21 patients had (34.4\%) perioperative complications, including minor (C-D grade 1-2) complications in eight patients (13.1\%) and major (C-D grade 3-4) complications in 13 patients (21.3\%). The

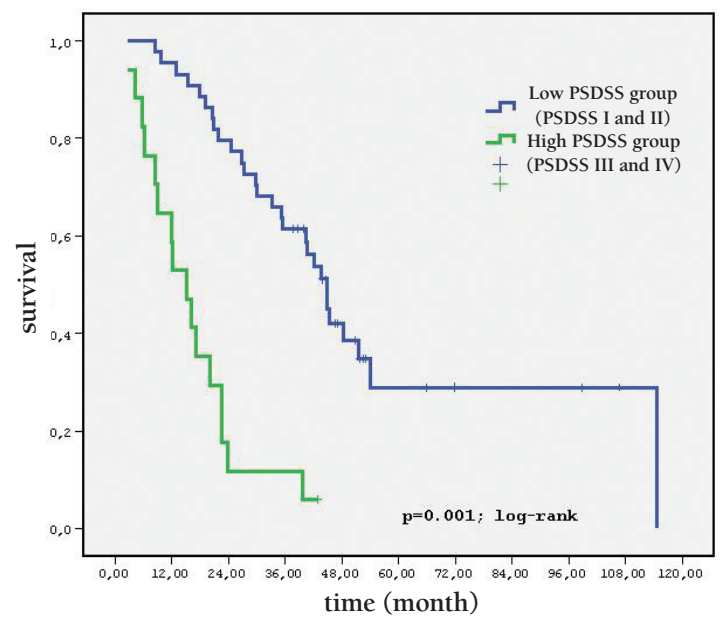

Graphic 1. Kaplan-Meier curves of low and high Peritoneal Surface Disease Severity score (PSDSS) groups. Mean survival in low PSDSS group (PSDSS 1 and 2): 57.2 \pm 6.7 months, mean survival in high PSDSS group (PSDSS 3 and 4): $16.5 \pm 2.6$ months

PSDSS: Peritoneal Surface Disease Severity score

Table 1. Calculation of Peritoneal Surface Disease Severity score and formation of groups

\begin{tabular}{|c|c|c|}
\hline Clinical symptoms & PCI & Histopathological features \\
\hline No symptoms=0 point & $\mathrm{PCI}<10=1$ point & Well or moderately differentiated and $\mathrm{N} 0=1$ point \\
\hline Mild symptoms=1 point & $10<\mathrm{PCI}<20=3$ points & Moderately differentiated and N1/N2=3 points \\
\hline Severe symptoms $=6$ points & $\mathrm{PCI}>20=7$ points & Poorly differentiated or signet ring cell tumor $=9$ points \\
\hline \multicolumn{3}{|c|}{ PSDSS is graded according to the total score of these three components } \\
\hline PSDSS score & \multicolumn{2}{|l|}{ PSDSS Group } \\
\hline $2-3$ & \multicolumn{2}{|l|}{1} \\
\hline $4-7$ & \multicolumn{2}{|l|}{2} \\
\hline $8-10$ & \multicolumn{2}{|l|}{3} \\
\hline$>10$ & \multicolumn{2}{|l|}{4} \\
\hline
\end{tabular}

PSDSS: Peritoneal Surface Disease Severity score, PCI: Peritoneal cancer index, N: Node

Mild symptoms: $<10 \%$ weight loss, mild abdominal symptoms, asymptomatic ascites,

Severe symptoms: $>10 \%$ weight loss, unremitting pain, bowel obstruction, symptomatic ascites 
Table 2. Demographic, clinical and oncologic follow-up data of patients

\begin{tabular}{|c|c|c|c|c|c|}
\hline & & & $\begin{array}{l}\text { Low PSDSS (PSDSS 1-2) } \\
(\mathrm{n}=44)\end{array}$ & $\begin{array}{l}\text { High PSDSS } \\
\text { (PSDSS 3-4) }(n=17)\end{array}$ & $\mathrm{p}$ \\
\hline \multicolumn{3}{|l|}{ Age, mean } & $53.7 \pm 12.8$ & $52.5 \pm 17.4$ & 0.803 \\
\hline \multirow{2}{*}{\multicolumn{2}{|c|}{ Gender }} & Male & 18 & 7 & \multirow{2}{*}{0.604} \\
\hline & & Female & 26 & 10 & \\
\hline \multicolumn{3}{|c|}{ Synchronous disease } & 17 & 10 & \multirow{2}{*}{0.250} \\
\hline \multicolumn{3}{|c|}{ Metachronous disease } & 27 & 7 & \\
\hline \multicolumn{3}{|l|}{ Mean PCI score } & $11.02 \pm 3.9$ & $17.71 \pm 8.0$ & 0.001 \\
\hline \multicolumn{3}{|c|}{ Operative time, minutes } & $296.4 \pm 101.6$ & $343.1 \pm 139.3$ & 0.212 \\
\hline \multicolumn{3}{|l|}{ Need for ICU } & $7(15.9 \%)$ & $4(23.5 \%)$ & 0.481 \\
\hline \multicolumn{3}{|c|}{ Length of ICU stay, days } & $1.2 \pm 0.4$ & $1.7 \pm 0.9$ & 0.09 \\
\hline \multicolumn{3}{|c|}{ Length of hospital stay after surgery, days } & $13.9 \pm 10.2$ & $18.1 \pm 10.1$ & 0.386 \\
\hline \multirow{3}{*}{ Complication } & All complications & & $14(31.8 \%)$ & $7(41.2 \%)$ & 0.555 \\
\hline & Minor (C-D 1-2) & & $6(13.6 \%)$ & $2(11.7 \%)$ & \multirow{2}{*}{0.656} \\
\hline & Major (C-D 3-4) & & $8(18.2 \%)$ & $5(29.5 \%)$ & \\
\hline \multicolumn{3}{|l|}{ Recurrence } & $24(54.5 \%)$ & $12(70.6 \%)$ & 0.385 \\
\hline \multicolumn{3}{|l|}{ Mortality } & $28(63.6 \%)$ & $16(94.1 \%)$ & 0.024 \\
\hline \multicolumn{3}{|c|}{ Mean survival time, months } & $57.21 \pm 6.7$ & $16.55 \pm 2.6$ & 0.001 \\
\hline
\end{tabular}

mean follow-up was 35.0 23.2 (range, 3.2-114.7) months. Recurrence (distant metastasis in six patients, intraabdominal recurrence in 14 patients, intra-abdominal recurrence and distant metastasis in 16 patients) was observed in 36 patients (59\%). During the follow-up, 44 patients (72.1\%) died. The mean survival was 46.5 \pm 5.5 months (K-M), with $1-, 3$ - and 5 -year survival rates of $85 \%, 47 \%$, and $21 \%$, respectively (K-M). There was no statistically significant difference between low and high PSDSS groups in terms of operative time, postoperative ICU follow-up, ICU stay and hospital stay $(\mathrm{p}=0.212$; independent Samples t-test, $\mathrm{p}=0.481$; chisquare test, $\mathrm{p}=0.09$; independent Samples t-test, $\mathrm{p}=0.386$; independent Samples t-test, respectively). There was no statistically significant relationship between morbidity and recurrence and low and high PSDSS groups $(\mathrm{p}=0.486$ and $\mathrm{p}=0.385$, respectively; chi-square test). During the followup, $94.1 \%$ of the patients in the high PSDSS group died, while $63.6 \%$ of the patients in the low PSDSS group died ( $p=0.024$; chi-square test). The mean survival of patients in the low PSDSS group was significantly longer than in the high PSDSS group [57.2 \pm 6.7 months vs. 16.5 \pm 2.6 months (C-M)] ( $\mathrm{p}=0.001$; log-rank test) (Graphic 1). Postoperative follow-up data of the patients are summarized in Table 2.

\section{Discussion}

The aim of CRS in PMCO is the resection of locally advanced primary disease and peritoneal metastatic foci without leaving macroscopic disease, and the goal of complementary HIPEC is to treat potential microscopic residues after macroscopic eradication. Perioperative mortality decreased to $5 \%$ and morbidity decreased to 23$45 \%$ in patients undergoing CRS and HIPEC for PMCO due to increased surgical technical experience, improvement of perioperative complex cancer care conditions, and more conscious multi-disciplinary approach on toxicity, nutrition and infection. ${ }^{15,16}$ In our series, perioperative mortality was $3.2 \%$ and morbidity was $34.4 \%$. Despite all these improvements, CRS and HIPEC treatment have a relatively high mortality and morbidity risk, requiring high cost and center experience. The selection of patients to perform this marathon complex surgery is one of the most important issues. In 2008, a consensus report containing eight radiological and clinical variables was published to achieve complete cytoreduction in patients with $\mathrm{PMCO},{ }^{17}$ which recommended the surgical treatment of patients with an Eastern Cooperative Oncology group (ECOG) performance score $\leq 2$, but all variables except the ECOG performance score are related to the spread of malignant disease. It has 
been shown in many studies that histology of the primary tumor is also important; especially the presence of signet ring cell carcinoma has been shown to be a marker of poor prognosis. ${ }^{18,19} \mathrm{PCI}$ is most commonly used for the evaluation of the extent of carcinomatosis, another component of PSDSS described by Pelz et al. ${ }^{9}$ In a study by Elias et al. ${ }^{20}$ in a series of 523 patients with PMCO, they stated a PCI $\geq 17$ as a predictor of poor prognosis. Similarly, Goéré et al. ${ }^{21}$ stated a PCI $\geq 20$ as a predictor of poor prognosis in their study of 180 patients. There are publications that detected a negative correlation between survival and PCI as in these studies, ${ }^{22,23}$ and there is also a study of 50 patients reported that PCI is more effective than PSDSS in predicting prognosis. ${ }^{6} \mathrm{PCI}$ values used to evaluate PSDSS are obtained by examining preoperative abdominal contrast enhanced CT scans. There is no consensus on the sensitivity and specificity of contrast-enhanced CT in assessing the extent of peritoneal implants in patients with PMCO. In the initial studies in the literature, over $90 \%$ sensitivity was reported in lesions over $5 \mathrm{~cm}$, this rate decreases below 25\% in implants below $5 \mathrm{~mm} .{ }^{24}$ Also, except for implant size, the type of the lesion (nodular or plaque), location (inside the intestine loop, solid organ neighborhood, etc.) and the experience of the radiologist affect CT sensitivity. ${ }^{25}$ In studies involving experienced radiologists in large-scale centers, it was shown that there was a high correlation between intraoperative PCI values and preoperative PCI values, but it was found that $\mathrm{PCI}$ values calculated by $\mathrm{CT}$ in the preoperative period were lower than the intraoperative PCI values. ${ }^{26,27,28}$ In our study, a study conducted as a specialty thesis in medicine also showed a high correlation between intraoperative and preoperative PCI values, but lower preoperative PCI scores were calculated compared to intraoperative PCI scores. ${ }^{29}$ In the light of this information, it can be said that the PCI value calculated by CT scans can be used safely considering that it may be a little low. In our study, the mean operative time of the patients in the low PSDSS group was shorter than the patients in the high PSDSS group (296 minimum vs 343 minimum), and those patients with better overall performance status needed less postoperative ICU followup (16\% vs $23 \%)$ and they were discharged sooner after surgery (14 days vs 18 days), but there was no statistically significant difference between these values. There was also no statistical significance between perioperative complications between the groups. In the literature, there are no studies evaluating the relationship between PSDSS and these parameters in patients with PMCO, and statistical significance may be seen between these parameters in larger patient groups. In a series of 40 patients who underwent CRS and HIPEC for PMCO, Pelz et al. ${ }^{9}$ reported that the mean survival of the PSDSS 4 group was worse and that the inclusion in the PSDSS 4 group was a poor prognostic marker. In a study of 56 patients undergoing CRS and HIPEC due to PMCO published in 2010, Chua et al. ${ }^{11}$ showed that PSDSS was an independent prognostic marker for survival. In a multicenter study published in 2014, 1013 patients diagnosed with PMCO who underwent CRS and HIPEC in 609 patients were examined and PSDSS was found to be effective in predicting median survival. ${ }^{12}$ In a series of 49 patients with heterogeneous primers by Yoon et al. ${ }^{13}$ Thirty three patients were treated with CRS and HIPEC, and PSDSS 3 and 4 were reported to be associated with unresectability. There are also studies reporting that PSDSS is effective in predicting survival in patients undergoing CRS due to ovarian and appendix mucinous neoplasm. ${ }^{30,31}$ In our study, supporting the literature, it was found that the patients in the low PSDSS group had longer mean survival, and that PSDSS was effective in predicting overall mortality. The potential limitations of our study are inclusion of data from a single center, a relatively limited number of patients and retrospective analysis of these data. In conclusion, the findings of this study supports that PSDSS is a valid, easy to apply and non-invasive scoring system that can be used safely in the selection and evaluation of patients with PMCO before CRS and HIPEC.

\section{Ethics}

Ethics Committee Approval: The study was approved by the Dokuz Eylül University Local Ethics Committee (approval number: 2017/25-36).

Informed Consent: Written informed consent was obtained from the patients.

Peer-review: Internally peer-reviewed.

\section{Authorship Contributions}

Surgical and Medical Practices: S.S., C.A., A.E.C., I.B.A., C.A., F.O., S.S., N.C..A., Concept: S.S., C.A., A.E.C., F.O., S.S., N.Ç.A., Data Collection or Processing: C.A., N.Ç.A., S.S., A.E.C., I.B.A., C.A., Analysis or Interpretation: C.A., S.S., I.B.A., C.A., F.O., S.S., N.C..A., Literature Search: C.A., N.Ç.A., S.S., A.E.C., I.B.A., C.A., Writing: C.A., S.S., N.Ç.A., A.E.C., I.B.A., C.A., F.O., S.S.

Conflict of Interest: No conflict of interest was declared by the authors.

Financial Disclosure: The authors declared that this study received no financial support.

\section{References}

1. Kerscher AG, Chua TC, Gasser M, Maeder U, Kunzmann V, Isbert C, Germer CT, Pelz JO. Impact of peritoneal carcinomatosis in the disease history of colorectal cancer management: A longitudinal experience of 2406 patients over two decades. Br J Cancer 2013;108:1432-1439.

2. Jayne DG, Fook S, Loi C, Seow-Choen F. Peritoneal carcinomatosis from colorectal cancer. Br J Surg. 2002;89:1545-1550. 
3. Nadler A, McCart JA, Govindarajan A. Peritoneal Carcinomatosis from Colon Cancer: A Systematic Review of the Data for Cytoreduction and Intraperitoneal Chemotherapy. Clin Colon Rectal Surg 2015;28:234-246.

4. Behrenbruch C, Hollande F, Thomson B, Michael M, Warrier SK, Lynch C, Heriot A. Treatment of peritoneal carcinomatosis with hyperthermic intraperitoneal chemotherapy in colorectal cancer. ANZ J Surg 2017;87:665-670

5. da Silva RG, Suqarbaker PH. Analysis of prognostic factors in seventy patients having a complete cytoreduction plus perioperative intraperitoneal chemotherapy for carcinomatosis from colorectal cancer. J Am Coll Surg 2006;203:878-886.

6. Ng JL, Ong WS, Chia CS, Tan GH, Soo KC, Teo MC. Prognostic Relevance of the Peritoneal Surface Disease Severity Score Compared to the Peritoneal Cancer Index for Colorectal Peritoneal Carcinomatosis. Int J Surg Oncol 2016;2016:1-8.

7. Yan TD, Black D, Savady R, Suqarbaker PH. Systematic review on the efficacy of cytoreductive surgery combined with perioperative intraperitoneal chemotherapy for peritoneal carcinomatosis from colorectal carcinoma. J Clin Oncol 2006;20:4011-4019.

8. Chua TC, Esquivel J, Pelz JO, Morris DL. Summary of current therapeutic options for peritoneal metastases from colorectal cancer. J Surg Oncol 2013;107:566-573.

9. Pelz JO, Stojadinovic A, Nissan A, Hohenberger W, Esquivel J. Evaluation of a peritoneal surface disease severity score in patients with colon cancer with peritoneal carcinomatosis. J Surg Oncol 2009;99:9-15.

10. Pelz JO, Chua TC, Esquivel J, Stojadinovic A, Doerfer J, Morris DL, Maeder U, Germer CT, Kerscher AG. Evaluation of Best Supportive Care and Systemic Chemotherapy as Treatment Stratified according to the retrospective Peritoneal Surface Disease Severity Score (PSDSS) for Peritoneal Carcinomatosis of Colorectal Origin. BMC Cancer 2010;10:689.

11. Chua TC, Morris DL, Esquivel J. Impact of the peritoneal surface disease severity score on survival in patients with colorectal cancer peritoneal carcinomatosis undergoing complete cytoreduction and hyperthermic intraperitoneal chemotherapy. Ann Surg Oncol 2010;17:1330-1336.

12. Esquivel J, Lowy AM, Markman M, Chua T, Pelz J, Baratti D, Baumgartner JM, Berri R, Bretcha-Boix P, Deraco M, Flores-Ayala G, Glehen O, GomezPortilla A, González-Moreno S, Goodman M, Halkia E, Kusamura S, Moller M, Passot G, Pocard M, Salti G, Sardi A, Senthil M, Spilioitis J, TorresMelero J, Turaga K, Trout R. The American Society of Peritoneal Surface Malignancies (ASPSM) Multiinstitution Evaluation of the Peritoneal Surface Disease Severity Score (PSDSS) in 1,013 Patients with Colorectal Cancer with Peritoneal Carcinomatosis. Ann Surg Oncol 2014;21:4195-4201.

13. Yoon W, Alame A, Berri R. Peritoneal Surface Disease Severity Score as a predictor of resectability in the treatment of peritoneal surface malignancies. Am J Surg 2014;207:403-407.

14. Clavien PA, Barkun J, de Oliveira ML, Vauthey JN, Dindo D, Schulick RD, de Santibañes E, Pekolj J, Slankamenac K, Bassi C, Graf R, Vonlanthen R, Padbury R, Cameron JL, Makuuchi M. The Clavien-Dindo classification of surgical complications: five-year experience. Ann Surg 2009;250:187-196.

15. Stephens AD, Alderman R, Chang D, Edwards GD, Esquivel J, Sebbag G, Steves MA, Sugarbaker PH. Morbidity and mortality analysis of 200 treatments with cytoreductive surgery and hyperthermic intraoperative intraperitoneal chemotherapy using the coliseum technique. Ann Surg Oncol 1999;6:790-796

16. Goéré D, Sourrouille I, Gelli M, Benhaim L, Faron M, Honoré C. Peritoneal Metastases from Colorectal Cancer: Treatment Principles and Perspectives. Surg Oncol Clin N Am 2018;27:563-583.

17. Esquivel J, Elias D, Baratti D, Kusamura S, Deraco M. Consensus statement on the loco regional treatment of colorectal cancer with peritoneal dissemination. J Surg Oncol 2008;98:263-267.
18. Kwakman R, Schrama AM, van Olmen JP, Otten RH, de Lange-de Klerk ES, de Cuba EM, Kazemier G, Te Velde EA. Clinicopathological parameters in patient selection for cytoreductive surgery and hyperthermic intraperitoneal chemotherapy for colorectal cancer metastases a meta-analysis. Ann Surg 2016;263:1102-1111.

19. Winer J, Zenati M, Ramalingam L, Jones H, Zureikat A, Holtzman M, Lee K, Ahrendt S, Pingpank J, Zeh HJ, Bartlett DL, Choudry HA. Impact of aggressive histology and location of primary tumor on the efficacy of surgical therapy for peritoneal carcinomatosis of colorectal origin. Ann Surg Oncol 2014;21:1456-1462.

20. Elias D, Gilly F, Boutitie F, Quenet F, Bereder JM, Mansvelt B, Lorimier G, Dubè P, Glehen O. Peritoneal Colorectal Carcinomatosis Treated With Surgery and Perioperative Intraperitoneal Chemotherapy: Retrospective Analysis of 523 Patients From a Multicentric French Study From the Institut. J Clin Oncol 2009;28:63-68.

21. Goéré D, Souadka A, Faron M, Cloutier AS, Viana B, Honoré C, Dumont F, Elias D. Extent of Colorectal Peritoneal Carcinomatosis: Attempt to Define a Threshold Above Which HIPEC Does Not Offer Survival Benefit: A Comparative Study. Ann Surg Oncol 2015;22:2958-2964.

22. Huang Y, Alzahrani NA, Chua TC, Liauw W, Morris DL. Impacts of peritoneal cancer index on the survival outcomes of patients with colorectal peritoneal carcinomatosis. Int J Surg 2016;32:65-70.

23. Faron M, Macovei R, Goéré D, Honoré C, Benhaim L, Elias D. Linear Relationship of Peritoneal Cancer Index and Survival in Patients with Peritoneal Metastases from Colorectal Cancer. Ann Surg Oncol 2015;23:114-119

24. Archer AG, Sugarbaker PH, Jelinek JS. Radiology of peritoneal carcinomatosis. Cancer Treat Res 1996;82:263-288.

25. De Bree E, Koops W, Kröger R, Van Ruth S, Witkamp AJ, Zoetmulder FA. Peritoneal Carcinomatosis from Colorectal or Appendiceal Origin: Correlation of Preoperative CT with Intraoperative Findings and Evaluation of Interobserver Agreement. J Surg Oncol 2004;86:64-73.

26. Koh JL, Yan TD, Glenn D, Morris DL. Evaluation of preoperative computed tomography in estimating peritoneal cancer index in colorectal peritoneal carcinomatosis. Ann Surg Oncol 2009;16:327-333.

27. Duhr CD, Kenn W, Kickuth R, Kerscher AG, Germer CT, Hahn D, Pelz JO Optimizing of preoperative computed tomography for diagnosis in patients with peritoneal carcinomatosis. World J Surg Oncol 2011;9:171.

28. Esquivel J, Chua TC, Stojadinovic A, Melero JT, Levine EA, Gutman M, Howard R, Piso P, Nissan A, Gomez-Portilla A, Gonzalez-Bayon L, Gonzalez-Moreno S, Shen P, Stewart JH, Sugarbaker PH, Barone RM, Hoefer R, Morris DL, Sardi A, Sticca RP. Accuracy and clinical relevance of computed tomography scan interpretation of peritoneal cancer index in colorectal cancer peritoneal carcinomatosis: A multi-institutional study. J Surg Oncol 2010;102:565-570.

29. Vardar BU. Peritoneal Karsinomatozisin Preoperatif Evrelendirilmesinde Bilgisayarlı Tomografinin Etkinliği. 2018.

30. Esquivel J, Garcia SS, Hicken W, Seibel J, Shekitka K, Trout R. Evaluation of a new staging classification and a Peritoneal Surface Disease Severity Score (PSDSS) in 229 patients with mucinous appendiceal neoplasms with or without peritoneal dissemination. J Surg Oncol 2014;110:656-660.

31. Foster JM, Sleightholm R, Smith L, Ceelen W, Deraco M, Yildirim Y, Levine E, Muñoz-Casares C, Glehen O, Patel A, Esquivel J. The American Society of Peritoneal Surface Malignancies Multi-Institution evaluation of 1,051 advanced ovarian cancer patients undergoing cytoreductive surgery and HIPEC: An introduction of the peritoneal surface disease severity score. J Surg Oncol 2016;11:779-784 